\title{
Penggunaan ICT dalam Penyusunan Modul Statistika
}

\author{
Tri Hidayati ${ }^{1}$, Ita Handayani ${ }^{2}$, dan Ines Heidiani Ikasari ${ }^{3}$ \\ 1,2,3 Teknik Informatika,Universitas Pamulang, Tangerang Selatan, Indonesia \\ e-mail: $\left\{{ }^{1} \operatorname{dosen} 01385,{ }^{2} \operatorname{dosen} 01947,{ }^{3} \operatorname{dosen} 01374\right\} @$ unpam.ac.id
}

\begin{abstract}
Abstrak
In this study, the objectives to be achieved are teaching material products in the form of information technology-based statistical modules (Information and communication technology). This study uses the development of the ADDIE model in the preparation of the module. The ADDIE model consists of analysis (analysis), design (design), development (development), implementation (implementation) and the last is evaluation (evaluation). In the ADDIE model, the module developed contains valid, practical and effective criteria. Validity criteria refer to the validity of experts and practitioners. For the practicality of modules developed, based on the instrument in the form of a questionnaire. While for module effectiveness, it can be seen from the value of student achievement. The results of this study indicate that the modules developed meet valid criteria which fall into the very good category. For the module practicality criteria, the research shows that the module falls into a very good category based on the observations of the implementation of lecturers' learning and assessment. Based on student responses, the developed statistical modules fall into the good category. As for the effectiveness category, based on student achievement, the module can be classified as effective.
\end{abstract}

Kata Kunci: Development, modules, statistics, ADDIE, ICT

\section{Pendahuluan}

Statistika merupakan mata kuliah yang sangat penting dipelajari oleh mahasiswa, karena dapat digunakan dalam berbagai bidang. Mahasiswa yang mempelajari statistika diharapkan dapat mengatasi berbagai persoalan yang muncul dalam konteks keseharian yang berhubungan dengan konsep statistika. Oleh karena itu, mahasiswa mampu menerapkan ilmu yang mereka pelajari dalam kehidupan nyata di masyarakat. Kendati statistika merupakan mata kuliah yang sangat penting dikuasai mahasiswa namun banyak mahasiswa yang menganggap bahwa statistika merupakan matakuliah yang sulit dipelajari.

Chance, delMas, \& Garfield (2004) menyatakan bahwa berdasar pada berbagai kajian atas pengajaran statistika selama 20 tahun terakhir, pengajaran statistika masih sangat mengecewakan, khususnya pada mahasiswa yang mengambil mata kuliah wajib statistika. Meskipun model pengajaran telah banyak berkembang sedemikian banyak, namun model pengajaran pada perkuliahan statistika masih menggunakan format dan cara yang sudah usang. Oleh karena itu, pengajaran dan pembelajaran yang menggunakan model mutakhir perlu dikembangkan. Dengan menggunakan pendekatan modern mampu memberikan hasil yang lebih baik pada mahasiswa. Pengajar statistika perlu menggunakan teknologi terbaru sehingga materi statistika yang disampaikan pada mahasiswa akan lebih menarik dan tidak membosankan. Penggunaan teknologi komunikasi merupakan salah satu alternatif dalam pembelajaran yang mampu memberikan nuansa baru bagi mahasiswa.

Widiana (2016) menyatakan bahwa modul elektronik atau madia berbasis teknologi informatika memiliki dampak positif pada kemampuan pemecahan masalah peserta didik. Selain itu, Hendikawati\&Arini (2016) juga berpendapat bahwa modul yang disusun dengan basis ICT mampu meningkatkan kemampuan komunikasi matematis mahasiswa. Teknologi komunikasi pada umumnya memberi kemudahan dalam tukar dan alih pengetahuan. Prinsip guna tersebut juga bisa diterapkan pada penyusunan media belajar yang mudah untuk diterima dan dipahami peserta didik. 
Hasil dari pengamatan awal di tempat penelitian, menunjukkan bahwa (1) mahasiswa merasa bahwa mata kuliah statistika sukar untuk dipahami, terutama beberapa materi terkait jenis data, pengumpulan data, uji prasyarat dalam uji kesamaan rata-rata yaitu uji normalitas dan uji homogenitas. Kendala-kendala yang dihadapi mahasiswa tersebut disebabkan karena mereka memiliki daya motivasi yang kurang dalam belajar dan rendahnya intensitas mereka dalam mengerjakan berbagai varian soal terkait statistika. (2) Selama proses pembelajaran dosen belum membuat modul mata kuliah, dosen juga masih menggunakan metode pembelajaran yang berpusat pada dosen belum mengimplementasikan sistem pembelajaran yang inovatif dan menggunakan berbagai media pendukung pembelajaran (seperti perangkat lunak AMOS, SPSS, LISREL dan Microsoft Excel) sehingga pembelajaran yang dialami mahasiswa kurang berkesan.

Modul pembelajaran statistika berbasis ICT diduga dapat membantu mahasiswa dalam memahami materi yang sedang diajarkan. Dengan modul statistika berbasis ICT mahasiswa dapat mempraktekkan langsung dengan Ms. Excel maupun dengan SPSS. Mahasiswa yang belajar dengan mempraktekkan langsung akan meningkatkan pemahamannya karena mahasiswa tersebut dapat mengkonstruksi pengetahuannya sendiri. Mahasiswa juga dapat termotivasi dalam belajar statistika karena pembelajaran yang sedang dialami sangat berkesan. Mahasiswa mendapatkan pengalaman yaitu tentang software yang dapat digunakan dalam menganalisis data yang didapatkan. Hal ini sejalan dengan Liebman (2010), mahasiswa yang mempraktekkan ilmu statistika dengan menerapkan apa yang mereka pelajari dengan melakukan analisis data yang mereka dapatkan akan meningkatkan pemahaman yang mendalam.

Berdasarkan hal di atas peneliti tertarik untuk mengembangkan bahan ajar yang di dalamnya memuat unsur teknologi baik berupa alat untuk menggali informasi, maupun sebagai sarana informasi. Bahan ajar yang akan dikembangkan berupa modul. Dari hal tersebut, perlu adanya sebuah penelitian yang bertujuan untuk mengembangkan sebuah modul statistika yang berbasis teknologi informasi dan komunikasi dengan berorientasi pada prestasi belajar mahasiswa.

\section{Metode Penelitian}

Model pengembangan yang digunakan dalam penelitian ini adalah model ADDIE. Model ini cocok digunakan untuk mengembangkan media pembelajaran karena memungkinkan adanya proses evaluasi dalam setiap tahapannya. Dengan hal tersebut, memungkinkan terciptanya suatu produk yang bisa diterapkan dengan baik pada subjek uji coba di dalam sebuah kelas.

Model ADDIE dikembangkan oleh Reiser dan Mollenda (Branch. 2009). Penelitian ini bertujuan untuk mengembangkan bahan ajar statistik berbasis ICT (Information and Communication Technology) yang berorientasi pada prestasi belajar mahasiswa. Tahapan-tahapan yang dilaksanakan dalam mengembangkan modul statistika berbasis teknologi informasi dan komunikasi pada penelitian ini adalah sebagai berikut (Branch, 2009): 1) Tahap analisis pada tahap ini, peneliti melakukan analisis kebutuhan mahasiswa dan analisis materi statistika yang diajarkan. Pada tahap ini akan dihasilkan karakteristik dan gambaran umum mahasiswa serta bentuk dan detail materi yang diajarkan dalam kuliah statistika, baik kekurangannya dan segi yang harus diperbaharui. 2) Tahap perancangan (design), pada kegiatan perancangan (design) disusun Rencana Kegiatan Pembelajaran Semester (RKPS) dan bahan ajar (modul) mata kuliah Statistika. Rancangan penelitian pengembangan modul statistika berbasis pada teknologi informasi dan komunikasi yang berorientasi pada prestasi belajar mahasiswa, 3) Tahap pengembangan (development), perangkat yang dikembangkan meliputi bahan ajar statistik berbasis ICT (Information and Communication Technology) yang berorientasi pada prestasi belajar mahasiswa berdasarkan validasi ahli dan revisi produk I selanjutnya validasi ahli dilakukan oleh 2 dosen ahli yakni dosen ahli Statistika dan dosen ahli bahan ajar serta satu orang praktisi yakni dosen pengampu mata kuliah Statistika, 4) Tahap implementasi (implementation), pengujian yang dilaksanakan adalah pengujian lapangan terbatas pada mahasiswa dalam kelas statistika yang dijadikan subjek uji coba. Implementasi dilaksanakan agar memperoleh data yang 
digunakan dalam menentukan kategori kepraktisan dan keefektifan modul statistika yang dikembangkan, 5) Tahap evaluasi (evaluation), pada tahap ini peneliti melakukan analisis data agar memperoleh feedback, sehingga modul yang dikembangkan bisa direvisi dengan baik. Serta, peneliti menganalisis apakah modul statistika yang dikembangkan telah memenuhi kategori kepraktisan dan keefektifan sesuai dengan yang ditentukan.

Dalam penelitian, mengambil mahasiswa Teknik Informatika Universitas Pamulang semester 3 Tahun Ajaran 2017/2018 sebagai subjek uji coba dalam pengembangan produk. Waktu pelaksanaan penelitian mencakup rentang dari bulan April sampai Juli 2018. Instrumen yang digunakan dalam pengumpulan data, yakni berupa (1) lembar validasi, (2) lembar penilaian dosen (praktisi), (3) lembar respon mahasiswa, (4) lembar observasi, (5) tes prestasi belajar. Data yang diperoleh digunakan untuk mengetahui tingkat kevalidan, kepraktisan, keefektifan modul statistika yang disusun.

\section{Hasil Penelitian dan Pembahasan}

Hasil pengembangan modul awal pada penelitian pengembangan berupa modul statistika berbasis ICT (Information and Communication Technology). Sebagaimana disampaikan di atas, pengembangan modul statistika ini menggunakan model ADDIE. Pada bagian ini peneliti akan menjabarkan hasil pengembangan produk, dimana tahapan yang dilewati dalam model ADDIE berupa analisis, perancangan, pengembangan, penerapan dan evaluasi.

Dalam tahap pertama yaitu tahap analisis, tahapan ini menjelaskan hasil penelitian analisis keutuhan dan analisis materi. Pada analisis kebutuhan dilaksanakan dengan cara melakukan pengamatan keterlaksanaan pembelajaran dan interview pada dosen pengampu mata kuliah Statistika pada program studi Teknik Informatika. Observasi dilakukan dengan tujuan untuk mendapatkan informasi tentang kondisi kelas, metode yang digunakan dan media belajar apa yang tersedia di program studi Teknik Informatika Universitas Pamulang. Analisis ini dilakukan sebagai acuan peneliti untuk menyusun modul yang akan dikembangkan. Kebutuhan yang pertama adalah terwujudnya suatu pengajaran yang inovatif dan mampu menumbuhkan minat dan motivasi pada pembelajaran. Selain itu, perlu adanya media pembelajaran berupa modul yang mampu meningkatkan motivasi dan prestasi mahasiswa.

Pada proses pengajaran mata kuliah statistika di kelas, perlu adanya banyak pembaharuan dan perubahan baik dalam strategi pengajaran maupun media pembelajaran nya. Perkuliahan statistika yang berjalan masih menekankan para proses drilling mahasiswa untuk melakukan pengerjaan soal. Dengan sistem pengajaran seperti ini menjadikan mahasiswa merasa bosan dan enggan untuk mengembangkan kompetensi statistika mereka. Di samping itu, media pembelajaran yang digunakan dan buku rujukannya kurang beragam dan inovatif. Pengajaran yang berlangsung lebih didominasi oleh kegiatan dosen dalam memberikan ceramah dan kurang memberi porsi yang lebih pada mahasiswa untuk berpendapat. Berdasarkan pada analisis kebutuhan tersebut, maka diperlukan suatu bahan ajar dan yang bisa mendorong rasa ingin tahu dan motivasi mahasiswa. Maka, perlu adanya penelitian yang bertujuan untuk menyajikan suatu bahan ajar yang bisa mengatasi permasalahan yang muncul tersebut. Dalam analisis materi dipilih mata kuliah Statistika dasar karena waktu pelaksanaan penelitian. Dalam mata kuliah Statistika dasar materi terdiri dari definisi Statistika, populasi dan sampel, teknik pengambilan sampel, definisi data dan jenis-jenis variabel, ukuran pemusatan data, ukuran penyebaran data, Penyajian data dalam tabel distribusi frekuensi, kemiringan dan keruncingan, uji normalitas dan uji homogenitas.

Tahap perencanaan (design), penyajian materi dalam modul mengikuti komponen yang ada dalam silabus dan RKPS. Selain itu, pengembangan juga mengacu pada usaha untuk mengoptimalkan motivasi dan prestasi belajar mahasiswa. Hasil dari tahap design berikutnya adalah instrumen evaluasi yakni instrumen tes prestasi belajar. Pada uji coba materi yang diambil adalah materi terkait penyusunan instrumen tes prestasi belajar mahasiswa materi ukuran pemusatan dan penyebaran data didasarkan pada tujuan pembelajaran yang ingin dicapai. Tes yang disusun adalah tes berbentuk uraian.

Tahap pengembangan (development), hasil yang diperoleh dari tahap design dan revisi 1 (revisi dari validator) kemudian direfleksikan dan 
dijadikan dasar untuk mengembangkan bahan ajar Statistika berbasis ICT (Information and Communication Technology). Pengembangan perangkat pembelajaran meliputi modul. Hasil pada tahap ini dinamakan draft 2 yang berupa modul yang diimplementasikan pada pembelajaran Statistika dasar. Pengembangan modul dengan menggunakan bantuan perangkat lunak Microsoft Word 2010, Microsoft Office Picture Manager 2010 dan Microsoft Paint 2010. Dengan mengikuti langkah-langkah penyusunan modul, maka modul Statistika berbasis ICT (Information and Communication Technology) berhasil disusun. Modul ini diberi judul "Modul Statistika Dasar, Panduan Bagi Dosen dan Mahasiswa". Bentuk modul berdimensi 8,27 X 11,69 inches. Modul ini dicetak menggunakan kertas HVS ukuran A4 dengan berat $80 \mathrm{mgr} /$ paper. Cover dicetak dengan kertas cover warna putih. Modul yang dikembangkan dicetak menggunakan printer Cannon MG2570 dengan tinta hitam putih dan warna. Adapun komponen yang terdapat pada modul statistika dasar yaitu cover, pendahuluan, kata pengantar, daftar isi, untuk masing-masing pertemuan terdiri atas judul materi (materi pokok), tujuan pembelajaran, isi materi, contoh soal, latihan soal dan daftar pustaka.

Produk awal yang telah selesai selanjutnya dilakukan validasi oleh validator. Dalam proses ini, peneliti melibatkan 3 validator, yakni berupa 2 ahli dan 1 praktisi (dosen). Berdasarkan hasil validasi ahli, rata-rata skor empiris modul Statistika berbasis ICT (Information and Communication Technology) yang disusun telah dinyatakan valid untuk diimplementasikan, dengan rata-rata skor empiris 68 dengan kriteria kevalidan dalam kategori sangat baik. Hasil proses tersebut menunjukkan bahwa modul statistika yang dikembangkan masuk dalam kategori valid, dengan kriteria sangat baik.

Dalam tahapan implementasi, bahan ajar yang sudah dikembangkan kemudian diujicobakan dalam pembelajaran pada matakuliah Statistika dasar pada Program Studi Teknik Informatika Universitas Pamulang. Uji coba dilaksanakan mulai tanggal 28 Mei 2018 sampai 29 Juni 2018. Setelah kegiatan pembelajaran berakhir secara keseluruhan, dilakukan tes prestasi belajar mahasiswa untuk mengetahui ketercapaian tujuan pembelajaran yang telah dilakukan. Secara umum, proses implementasi perangkat pembelajaran berjalan dengan baik dan sesuai rencana. Hasil dari tahap implementasi berupa data kepraktisan dan keefektifan.

Validasi ahli dilakukan dengan tujuan untuk menentukan kevalidan produk hasil pengembangan. Proses validasi dilakukan sebelum uji coba lapangan, yakni dengan memberikan produk berupa modul statistika yang dikembangkan kepada validator ahli agar diperiksa dan diberi skor penilaian berkaitan dengan kevalidan hasil pengembangan. Proses validasi ini melibatkan tiga validator yaitu dua ahli yakni ahli Statistika dan ahli Bahasa serta satu dosen Statistika. Berdasarkan validasi ahli, diketahui bahwa untuk validitas modul skor empiris yang diperoleh berdasarkan penilaian dari validator adalah 67,67. Ini berarti produk pengembangan berupa modul Statistika berbasis ICT (Information and Communication Technology) yang dihasilkan memenuhi kriteria valid dengan kategori sangat baik dan bisa diteruskan dalam tahap uji coba.

Pengujicobaan dilakukan untuk memperoleh data penilaian dosen dan data respon mahasiswa, data keterlaksanaan pembelajaran, serta data tes prestasi belajar mahasiswa. Data-data tersebut selanjutnya digunakan untuk mengetahui kepraktisan dan keefektifan modul Statistika berbasis ICT (Information and Communication Technology) yang dikembangkan. Uji coba bahan ajar dilaksanakan oleh dosen dan peneliti bertindak sebagai salah satu observer. Pengambilan data ini dilaksanakan dalam proses pembelajaran selama 4 kali pertemuan, yaitu dari tanggal 28 Mei 2018 sampai 29 Juni 2018.

\section{Tingkat Kelayakan Produk}

Analisis data kepraktisan mencakup tiga hal, yaitu analisis data hasil: (1) penilaian dosen, (2) respon mahasiswa, dan (3) observasi keterlaksanaan pembelajaran. Penilaian data ini dilakukan dengan cara meminta penilaian dari dosen yang melaksanakan uji coba modul Statistika berbasis ICT (Information and Communication Technology). Pengambilan ini dilakukan setelah proses pembelajaran secara keseluruhan berakhir. Penilaian ini meliputi penilaian terhadap modul. Dari penilaian didapat bahwa total nilai yang diperoleh adalah 137 berarti bahan ajar yang dihasilkan masuk ke dalam kategori sangat baik, 
sehingga bahan ajar yang dihasilkan dikatakan praktis. Meskipun sudah dinyatakan praktis berdasarkan penilaian dosen, tetapi ada komentar dan saran dari dosen yang perlu diperhatikan. Dosen menyampaikan komentar bahwa bahan ajar yang dikembangkan akan lebih baik lagi, jika diterapkan pada semua materi yang ada. Pada uji coba hanya dilakukan pada materi ukuran pemusatan dan penyebaran data. Hal ini mengingat keterbatasan waktu, dimana ada dalam bulan Ramadhan dan sudah menjelang akhir perkuliahan.

Respon yang diminta berkaitan dengan kemudahan, kemenarikan dan kemanfaatan dalam menggunakan modul yang dikembangkan. Data respon mahasiswa ditunjukkan dalam Tabel 1.

Tabel 1. Hasil Analisis Kepraktisan Berdasarkan Respon Mahasiswa terhadap Modul Tiap Aspek

\begin{tabular}{|c|c|c|c|}
\hline No & $\begin{array}{c}\text { Aspek } \\
\text { penilaain }\end{array}$ & $\begin{array}{l}\text { Nilai } \\
\text { Empiris }\end{array}$ & Kategori \\
\hline 1 & Kemudahan & 37,35 & Baik \\
\hline 2 & Kemenarikan & 8,39 & Baik \\
\hline 3 & Kemanfaatan & 3,97 & Baik \\
\hline & Total & 49.71 & Baik \\
\hline
\end{tabular}

Berdasarkan hasil analisis data tersebut, diketahui bahwa respon mahasiswa terhadap modul statistika yang dikembangkan masuk dalam kategori baik. Dilihat dari pencapaian tiap aspeknya, baik aspek kemudahan, kemenarikan maupun kemanfaatan, ketiganya berada pada kategori baik. Analisis tersebut memberikan bukti bahwa modul Statistika berbasis ICT (Information and Communication Technology) yang dihasilkan memenuhi kriteria praktis.

Pengambilan data hasil observasi keterlaksanaan pembelajaran dilakukan sebanyak 4 kali dalam proses pembelajaran di kelas. Data hasil kegiatan ini digunakan untuk mengetahui keterlaksanaan langkah-langkah pembelajaran dalam mata kuliah Statistika dasar. Observasi dilakukan oleh dua orang. Data hasil observasi secara keseluruhan masuk dalam kategori sangat baik dengan persentase $92,5 \%$ dilihat dari kegiatan dosen dan kegiatan mahasiswa selama perkuliahan.

Meskipun demikian, pada pertemuan ketiga keterlaksanaan pembelajaran pada aktivitas mahasiswa mencapai kategori baik. Maka, analisis di atas menunjukkan bahwa modul statistika yang dikembangkan telah mencapai kriteria praktis.

Hasil dari analisis penilaian dosen, respon mahasiswa, dan observasi keterlaksanaan pembelajaran menyimpulkan bahwa modul Statistika berbasis ICT (Information and Communication Technology) yang dihasilkan memenuhi kriteria praktis, sehingga layak untuk digunakan.

Keefektifan modul yang dikembangkan dapat ditinjau dari nilai tes prestasi belajar dalam mata kuliah Statistika dasar khususnya pada materi ukuran pemusatan dan penyebaran data. Setelah dilaksanakan pembelajaran dengan menggunakan bahan ajar yang dikembangkan, dilakukan tes prestasi belajar mahasiswa. Rata-rata nilai tes prestasi belajar mahasiswa adalah 82,84. Hal tersebut berarti bahwa rata-rata hasil prestasi belajar mahasiswa berada di atas kriteria yang ditentukan yakni lebih dari 75 . Terdapat 26 mahasiswa dari 31 mahasiswa yang tuntas. Dengan demikian, persentase ketuntasan secara klasikal yang dicapai lebih dari $80 \%$ yaitu sebesar $83,87 \%$. Hal ini berarti bahwa bahan ajar yang dikembangkan efektif ditinjau dari prestasi belajar mahasiswa. Hasil analisis data tersebut menunjukkan bahwa modul statistika yang dikembangkan telah efektif karena sebagaimana yang dijelaskan pada metode penelitian, bahan ajar yang dikembangkan bisa dikatakan efektif berdasarkan tes prestasi belajar mahasiswa jika hasil tes prestasi belajar mahasiswa secara klasikal menyatakan banyaknya mahasiswa yang mencapai kriteria minimal (> 75) mencapai 80\%.

$$
\text { Pengembangan bahan ajar (modul) }
$$

Statistika berbasis ICT (Information and Communication Technology) terdapat dua revisi produk. Revisi pertama dilakukan setelah tahapan development dan revisi kedua setelah tahapan implementation. Revisi modul dalam tahap pertama merupakan pengembangan modul statistika yang bersandar pada feedback validasi ahli. Pada tahap ini dilakukan perbaikan pada bahan ajar berdasarkan saran dan masukan dari validator. Revisi produk I menghasilkan bahan ajar yang akan diimplementasikan pada pembelajaran. Revisi produk tahap II merupakan pengembangan bahan ajar berdasarkan hasil uji coba. Tahap II ini menunjukkan adanya beberapa hal yang perlu diperbaiki pada modul. Untuk revisi untuk modul 
diantaranya agar ditambah lagi latihan soal agar mahasiswa lebih memahami materi yang telah dipelajari.

Pengembangan bahan ajar dalam penelitian ini telah dilakukan melalui beberapa tahapan, yaitu analisis kebutuhan, perencanaan produk, pengembangan modul, implementasi modul dan evaluasi. Melalui tahapan-tahapan tersebut, peneliti dapat mengetahui perbaikan apa yang diperlukan untuk kesempurnaan modul.

Menurut Nieveen (1999) suatu produk penelitian yang baik hendaknya memenuhi tiga kriteria berupa kevalidan, kepraktisan, dan keefektifan. Sehingga, berdasarkan analisis data dalam tahap validasi ahli dan uji coba lapangan, dapat diketahui bahwa modul statistika yang dikembangkan telah masuk dalam kriteria valid, praktis, dan efektif yang ditinjau dari prestasi belajar siswa.

Berdasarkan penilaian para ahli, produk akhir berupa modul Statistika berbasis ICT (Information and Communication Technology) telah memenuhi kriteria valid dengan kategori sangat baik. Modul Statistika berbasis ICT (Information and Communication Technology) yang dikembangkan telah melalui tahap revisi yang berlandaskan pada berbagai saran para ahli. Sehingga modul yang dikembangkan layak dan bisa diimplementasikan dalam pembelajaran. Bahan ajar valid karena dalam proses pengembangannya, penyusunan materi didasarkan pada teori-teori yang kuat dan relevan.

Uji coba lapangan memberikan hasil bahwa penilaian dosen yang menggunakan bahan ajar yang disusun tergolong pada kategori sangat baik. Hal ini karena modul statistika ini dikembangkan berdasarkan pada saran dan masukan yang diberikan dosen. Di samping itu, data respon mahasiswa yang mengikuti uji coba menggunakan modul yang dikembangkan menunjukkan bahwa modul statistika tersebut termasuk pada kategori baik. Dalam hal ini, mahasiswa menunjukkan rasa senang dengan adanya uraian materi serta bahasa yang digunakan dalam modul yang lebih gampang dan sederhana untuk dipahami. Selain itu juga, adanya contoh soal beserta penyelesaiannya membuat mahasiswa lebih mudah dalam memahami materi dan mengerjakan uji kompetensi yang ada. Terakhir, hasil pengamatan atas keterlaksanaan pembelajaran menggunakan modul statistika di kelas, memberikan simpulan bahwa tingkat keterlaksanaan pembelajaran masuk dalam kategori sangat baik. Berdasarkan hasil penilaian dosen, respon mahasiswa, dan hasil observasi keterlaksanaan pembelajaran tersebut, bisa dikatakan bahwa modul statistika yang dikembangkan bisa dikatakan masuk dalam kriteria praktis.

\section{Kesimpulan}

Pada hasil penelitian dan pembahasan yang telah dilaksanakan, menunjukkan bahwa 1) Modul Statistika berbasis ICT (Information and Communication Technology) yang dikembangkan masuk pada kriteria valid dengan tingkat kategori sangat baik, 2) Penyusunan modul statistika dengan basis teknologi informasi dan komunikasi memenuhi kriteria praktis, dengan kategori sangat baik berdasarkan penilaian guru, kategori baik berdasarkan respons mahasiswa, dan kategori sangat baik berdasarkan hasil observasi keterlaksanaan pembelajaran, 3) Pengembangan modul Statistika berbasis teknologi informasi dan komunikasi telah memenuhi kriteria efektif. Persentase mahasiswa yang masuk dalam kategori tuntas pada tes prestasi belajar sebanyak $83,87 \%$.

\section{Daftar Pustaka}

Branch, R. M. (2009). Instructional design: The ADDIE approach (Vol. 722). New York: Springer Science \& Business Media.

Chance, B., delMas, R., \& Garfield, J. (2004). Reasoning about sampling distributions. In D. Ben-Zvi \& J. Garfield (Eds.). The challenge of developing statistical literacy, reasoning, and thinking (pp. 295 - 323).

Furqon, P. D. (1999). Statistika terapan untuk penelitian. Bandung: Alfabeta,.

Gasperz, V, Statistical Process Control, PT Gramedia Pustaka Utama, Jakarta 1998.

Hendikawati, P., \& Arini, F. Y. (2016). Pengembangan Buku Ajar Statistika Berbantuan Tik Dengan Pendekatan Penilaian Portofolio Untuk Meningkatkan Komunikasi Dan Koneksi Matematis. Jurnal Penelitian Pendidikan, 33(2), 163-174.

Kwartolo, Y. (2010). Teknologi informasi dan komunikasi dalam proses pembelajaran. Jurnal Pendidikan Penabur, 14, 15-43. 
Leibman, Zipora. (2010). Integrating Real Life Data Analysis in Teaching Descriptive Statistics: A Constructivist Approach. Journal of Statistic Education. 18 , www.amstat.org/publications/jse/v18n1/libma n.pdf

Pribadi, B. A. (2009). Model desain sistem pembelajaran. Jakarta: Dian Rakyat

Somantri, A., \& Muhidin, S. A. (2006). Aplikasi Statistika dalam penelitian. Bandung: Pustaka Setia

Suyanto, E. (2010). Pembelajaran Berbasis ICT. Bandar Lampung.

Warsita, B. (2008). Teknologi Pembelajaran Landasan dan Aplikasinya. Jakarta: Rineka Cipta.

Widiana, I. W. (2016). E-Modul Berorientasi Pemecahan Masalah Dalam Pembelajaran Statistik Inferensial. Prosiding Seminar Nasional Hasil Penelitian dan Pengabdian kepada Masyarakat 2016: 529-540. Denpasar. 19-30 Agustus 2016. LPPM UNMAS: Denpasar.

Widoyoko, E. P. (2009). Evaluasi Program Pendidikan. Yogyakarta: Pustaka Belajar. 